\title{
UNESCO's mandate and recent activities for the rehabilitation of Afghanistan's cultural heritage
}

\author{
Christian MANHART*
}

\section{Afghanistan's cultural heritage}

A fghanistan, situated at an important junction on the ancient Silk Road, has been a crossroads of cultures since time immemorial. Its unique cultural heritage reflects a history marked by the complex indigenous encounter with A chaemenid Persia, A lexandrian Greece, Buddhism, Hinduism and Islam. A mong its many treasures are the Kanishka/Zoroastrian site of Surkh $\mathrm{K}$ otal, the ninth-century $\mathrm{N}$ ine Domes $\mathrm{M}$ osque of $\mathrm{H}$ aji Piyada, the twelfthcentury $\mathrm{M}$ inaret of Jam, and the walled city of Herat including the Friday Mosque, the Musallah complex with its minarets and the $\mathrm{G}$ awhar Shad mausoleum, the M ir A li Sher N avai M ausoleum, the Gazargah Shrine and the Shah Zadehah mausoleum; the fourth and fifth-century Buddha statues of the Bamiyan Valley were destroyed in M arch 2001 by the Taliban regime.

The present situation of A fghanistan's heritage, which has suffered irreversible damage and loss during the past two decades of war and civil unrest, can be described as a cultural disaster. For many years the U nited $\mathrm{N}$ ations, through its specialized agencies UNESCO and UNOCHA${ }^{1}$, and non-governmental organizations involved in the preservation of A fghanistan's cultural heritage have constantly made every possible effort to protect it and continue to do so.

\section{UNESCO's mandate in safeguarding Afghanistan's cultural heritage}

In January 2002 UNESCO was officially requested by A bdullah A bdullah, $M$ inister of Foreign A ffairs of the $A$ fghan interim administration, to play a coordinating role in all international and bilateral activities aimed at safeguarding A fghanistan's cultural heritage. A s a first step, a M emorandum of U nderstanding was signed in M arch 2002 with the A fghan

\footnotetext{
* The author is program specialist in charge of Asia at UNESCO's Division of Cultural Heritage.
} 
M inister of Information and Culture, Mr Said Makhdoom Raheen, which entrusted UNESCO with the coordination of international efforts for the $\mathrm{N}$ ational M useum of Kabul.

Following the request by the Afghan government, UNESCO responded firmly to the challenge of rehabilitating $A$ fghanistan's endangered cultural heritage. A s the U N Programme Secretariat for Education, Science and Culture, UNESCO is supporting the A fghan M inistry of Information and $\mathrm{C}$ ulture and related government agencies by coordinating all activities in the field of culture. The safeguarding of all aspects of the country's cultural heritage, both tangible and intangible, including museums, monuments, archaeological sites, music, art and traditional crafts, is of particular significance in terms of strengthening cultural identity and a sense of national integrity. C ultural heritage can become a point of mutual interest for former adversaries, enabling them to rebuild ties, to engage in dialogue and to work together in shaping a common future.

U N ESC 0 's strategy is to assist in the re-establishment of links between the populations concerned and their cultural history, helping them to develop a sense of common ownership of monuments that represent the cultural heritage of different segments of society. This strategy is therefore directly linked to the nation-building process within the framework of the $U$ nited $\mathrm{N}$ ation's mandate and concerted international efforts for the rehabilitation of A fghanistan. Referring to the UN Secretary-G eneral's dictum, "O ur challenge is to help the A fghans help themselves", policies and activities for the safeguarding of A fghanistan's cultural heritage focus on training and capacity-building activities related to the preservation of that heritage.

In M ay 2002 UNESCO, in cooperation with the A fghan M inistry of Information and Culture, organized the first International Seminar on the Rehabilitation of A fghanistan's C ultural $\mathrm{H}$ eritage. $\mathrm{H}$ eld in Kabul, it brought together 107 specialists on A fghan culture, as well as representatives of donor countries and institutions. Under the chairmanship of Makhdoom Raheen, M inister of Information and Culture of the A fghan government, the participants gave presentations on the state of conservation of cultural sites in the country and discussed programmes and coordination for the first conservation measures to be taken. This seminar resulted in more than US\$ 7 million being pledged for priority projects, allocated through bilateral agreements and U N ESC 0 Funds-in-Trust projects. A n eleven-page document

1 United Nations Educational, Scientifc and Cultural Organization (UNESCO), United Nations Office for the Coordination of Humanitarian Affairs (UNOCHA). 
containing concrete recommendations for future action was adopted, in which the need to en sure effective cooperation was emphasized.

Responding to the urgent need to enhance and facilitate the coordination of all international activities, and in accordance with the A fghan authorities, U NESCO has established an International Coordination Committee (ICC). Its statutes were approved by the 165th session of the organization's Executive Board in 0 ctober 2002. The Committee, which consists of A fghan experts and leading international specialists belonging to the most important donor countries and organizations providing funds or scientific assistance for the safeguarding of A fghanistan's cultural heritage, meets on a regular basis to review ongoing and future efforts to rehabilitate that heritage.

In June 2003, the Committee's First Plenary Session was organized at U N ESC $O$ headquarters in Paris. It was chaired by M akh doom Raheen in the presence of Prince $M$ irwais, seven representatives of the A fghan M inistry of Information and Culture, and more than 60 international experts participating as members of the Committee or as observers. The meeting resulted in specific recommendations for efficient coordination of actions to safeguard A fghanistan's cultural heritage to the highest international conservation standards. These recommendations concern key areas such as development of a long-term strategy, capacity-building, implementation of the World $\mathrm{H}$ eritage $\mathrm{C}$ onvention and the Convention on the $\mathrm{M}$ eans of Prohibiting and Preventing the Illicit Import, Export and Transfer of O wnership of Cultural Property, national inventories and documentation, as well as rehabilitation of the $\mathrm{N}$ ational $\mathrm{M}$ useum in $\mathrm{Kabul}$ and safeguarding of the sites of $\mathrm{Jam}, \mathrm{H}$ erat, and Bamiyan. Several donors pledged additional funding for cultural projects in A fghanistan following the meeting.

\section{Bamiyan}

The eyes of the world have been on the famous Bamiyan Valley since the destruction of the great Buddhist statues in early 2001: at 55 metres and 38 metres they were the tallest standing Buddhas in the world. The smaller of the two Buddhas is thought to have been carved into the sandstone cliffs of Bamiyan as long ago as the third century A.D. The demolition of the Bamiyan Buddhas was the result of a decree by Mullah 0 mar proclaimed in February 2001 and ordering "all non-Islamic statues and tombs considered offensive to Islam" to be destroyed.

Immediately after the fall of the Taliban regime in December 2001, UNESCO sent a mission to Bamiyan to assess the condition of the site and 
to cover the remaining large stone blocks with fibreglass sheets to protect them from harsh climatic conditions during winter. This first mission revealed that as a result of the explosions, cracks had appeared in the rock cliffs in and around the niches where the Buddha statues had previously stood. It also noted that not only the two large Buddha statues had been destroyed by the Taliban, but al so the smaller Kakrak Buddha.

M uch discussion has taken place in A fghanistan and all over the world about the future of this great site, revolving around the question of whether the two giant Buddha statues should be reconstructed. The participants at the First International Seminar on the Rehabilitation of A fghanistan's Cultural $\mathrm{H}$ eritage clearly recognized that the first emergency priority is to stabilize the cliff face with its niches and caves. N oting that the decision whether to engage in the reconstruction of the Buddha statues is a matter to be settled by the government and people of A fghanistan, it was agreed that reconstruction is not a priority as long as humanitarian aid for the A fghan people is urgently needed. Furthermore, the participants emphasized that the authenticity, integrity and historical importance of this great site need to be memorialized in an appropriate way, and that reconstruction of the statues therefore requires further discussion and careful consideration.

In July 2002 a second UNESCO mission jointly organized with the International C ouncil on M onuments and Sites (ICOM OS) and directed by its president, $\mathrm{M}$ ichael Petzet, was undertaken in order to prepare conservation measures at the Bamiyan site. A project preparation mission composed of German, Italian and Japanese experts then took place in September and 0 ctober 2002. It was found that over 80 per cent of the mural paintings dating from the sixth to the ninth century A D in the Buddhist caves have disappeared through neglect or looting. In one cave, experts even came across tools used by the thieves and the remains of freshly removed paintings. In view of this situation a contract was concluded through the A fghan Ministry of Information and Culture with the local commander, who immediately provided ten armed guards to keep the site under permanent surveillance, and no further thefts have been reported since. It was also observed with concern that the large cracks which have appeared in and around the niches could lead to the collapse of parts of them and of the inner staircases. The experts thereupon made additional measurements and advised on appropriate action to consolidate the cliffs and niches. A s a result of this mission, the Japanese Foreign M inistry generously approved a U N ESC O Fund-in-Trust for the safeguarding of the Bamiyan site for a total budget of more than U S\$ 1.8 million. 
ICOMOS financed the restoration of a Sunni mosque and another building, both of which are in close proximity to the niche of the larger Buddha. The aforesaid building is now being used to house the guards and store the project equipment.

A $n$ Expert W orking G roup on the preservation of the Bamiyan site was jointly organized by UNESCO and ICOMOS in Munich, Germany, in November 2002. Twenty-five A fghan and international experts evaluated the present state of the site, compared different conservation methods and issued recommen dations for implementation of the project's various activities. It was clearly reiterated that the statues should not be reconstructed. A fter delays due to the security situation resulting from the war in Iraq, the project was initiated in June 2003 with a three-week mission by architect $M$ ario Santana from Louvain U niversity for the scientific documentation of the back of the niches and the remaining fragments of the Buddhas.

During the First Plenary Session of the International Coordination Committee for the Safeguarding of A fghanistan's Cultural H eritage, which also took place in June 2003, a number of recommendations were made for the Bamiyan site. It was advised in particular that consolidation of the extremely fragile cliffs and niches and preservation of the mural paintings in the Buddhist caves be considered as priorities, as well as the preparation of an integrated master plan.

In order to prevent the collapse of the cliffs and niches, large scaffolding was supplied free of charge by the German M esserschmidt Foundation and transported by the German army to A fghanistan in A ugust 2003. With the help of this scaffolding and other imported specialized equipment, the internationally renowned Italian firm RODIO has successfully completed the first phase of the emergency consolidation of the cliffs and niches. In July, September and $O$ ctober 2003 several missions by specialists from the $\mathrm{N}$ ational Research Institute for Cultural Properties (Japan) were sent to Bamiyan to safeguard the mural paintings and to draw up a master plan for the long-term preservation and management of the site. A Japanese firm was commissioned to prepare a topographical map of the valley and a 3-D model of the cliffs and niches. In addition, U NESCO is helping the A fghan government to create a site museum which will be set up in a traditional house close to the site. To this end, the Swiss government recently approved a UNESCO Funds-in-Trust project for the restoration of a traditional mud-brick house in the old Bamiyan village, with a budget of U $S \$ 250,000$. Studies of the traditional houses will be conducted so as to recommend appropriate restoration methods. 
To ensure the coordination of all safeguarding activities in Bamiyan, a Second U N ESC O/ICO M OS Expert W orking G roup met in M unich, G ermany, in December 2003. Twenty-five experts took part in this meeting and evaluated the progress of consolidation, conservation and archaeological activities. They especially commended the consolidation methods applied and work carried out by the Italian firm RODIO, which recently succeeded in preventing the upper eastern part of the Small Buddha niche from collapsing. They also formulated specific follow-up recommendations, as well as a work plan for 2004 for final consolidation of the Small Buddha niche, conservation of the fragments of the two Buddha statues, preservation of the mural paintings and coordination of the archaeological work undertaken by the Délégation A rchéologique Française en A fghanistan (DAFA) and the National Research Institute for Cultural Properties (NRICP), Japan. In M arch 2004, a U NESC 0 mission composed of several experts from diverse fields went to the site to launch and coordinate follow-up work on finalizing the consolidation of the cliffs and niches, conserving the fragments of the Buddha statues and preserving the mural paintings.

\section{Jam and Herat}

The M inaret of Jam stands al one on a peninsula formed by the south bank of the $\mathrm{H}$ ari Rud river and the Jam river in a remote valley closely surrounded on all sides by mountains. 0 wing to its particularly isolated position, the existence of this most spectacular monument built at the end of the twelfth century was only rediscovered and confirmed in the late 1940s. Today, we know that at 65 metres it is not only the second-highest minaret in the world, but also one of the very few well-preserved architectural monuments from the $\mathrm{G}$ horid period.

The walled city of Herat, the capital of Herat Province and once, despite its turbulent history, a great centre of religion and culture, is known for its famous citadel ( $Q$ ala-i-Ikhtiyaruddin) in the heart of the old city, the stunningly decorated Friday Mosque (Masjid-I-Jami), the remains of the Musallah Complex with its minarets and the Gawhar-Shad's mausoleum topped by a flamboyant ribbed turquoise-blue dome.

In M arch 2002, U NESC $O$ sent two consultants to Jam and Herat. The architect Professor A ndrea Bruno and structural engineer $M$ arco $M$ en egotto assessed the state of conservation of the Minaret of Jam and of the Fifth $M$ inaret of $G$ awhar-Shad gardens, the $G$ awhar Shad mausoleum, the $C$ itadel, the Friday M osque and other monuments in $\mathrm{H}$ erat and drafted project documents for their conservation. Two months later, A ndrea Bruno, accompanied by a hydrologist, carried out a mission to advise on consolidating the Jam 
M inaret's foundations, stabilizing its overall structure and improving the flow of the two rivers. They al so recommended protective measures for the archaeological zone of Jam, threatened by illicit excavations. This mission revealed that, although the gabions (fortifying devices) installed by U N ESC 0 in 2000 were damaged during the dramatic flash floods of A pril 2002, they remained efficient in protecting the monument, which perhaps only survived as a result of this measure. The M inaret of Jam was inscribed as the first A fghan cultural property on the U N ESC O W orld Heritage List in June 2002. In O ctober and November 2002, architects Tarcis Stevens and M ario Santana drew up detailed metric documentation of the five minarets of the M usalla complex in Herat, as well as of the Jam M inaret. They combined this documentation with a preliminary training session for A fghan experts on the use of the Total Station (a laser theodolite) donated by U NESC $O$ to the A fghan M inistry of Information and Culture. This training will be continued in 2004.

A n Expert W orking G roup M eeting on the Preservation of Jam and the Monuments in Herat was held at UNESCO headquarters in January 2003. A mong the twenty-three participants were Sayed M akdoom Raheen, Zahir A ziz, A mbassador of A fghanistan to UNESCO, O mara Khan $M$ assoudi, Director of the $\mathrm{N}$ ational M useum of Kabul, and $\mathrm{A}$ bdul Wasey Feroozi, $\mathrm{H}$ ead of the A fghan Institute of A rchaeology. The experts evaluated the present state of conservation of the site of Jam and of the abovementioned historical monuments in Herat. They also addressed the problem of illicit excavations, compared different conservation methods and made emergency and long-term conservation and coordination proposals with reference to identified priorities. The concrete recommendations formulated by this W orking G roup enabled emergency activities to begin in 2003.

In N ovember 2002 the Swiss authorities approved a U N ESC 0 Fundsin-Trust project for emergency consolidation and restoration of the site of Jam, with a total budget of U S\$138,000. In addition, the Italian authorities granted US\$800,000, as cooperation with the UNESC 0 Funds-in-Trust programme, for emergency consolidation and restoration of monuments in Herat and Jam. These projects began in A pril 2003 with the reconstruction of a project house in Jam, the clearing of the Jam river bed and the repairing and strengthening of the wooden and metal gabions installed in 2000 and 2002 by U N ESC 0 and damaged in A pril 2002.

In July and A ugust 2003, the Italian experts A ndrea Bruno, Giorgio $M$ acchi and M ariachristina Pepe, together with representatives of U NESCO, carried out a mission to $\mathrm{H}$ erat and Jam to start preliminary work on a geological 
survey of the ground at the minarets, in preparation for their long-term consolidation. A t the same time the Fifth M inaret in Herat, which was in imminent risk of collapse, was temporarily stabilized by means of steel cables designed by Giorgio M acchi. This emergency intervention was successfully carried out by the Italian firm A LG A, in very difficult security and logistical conditions. The minaret isnow secured and stabilized, although it would probably not withstand severe earthquakes. The ground survey and the long-term consolidation of the Jam M inaret and the Fifth M inaret of Herat will be undertaken in 2004. In addition, three archaeologists from the Instituto per I'A frica e I'O riente ( $\mid$ sIA O), under UNESCO contract, carried out safeguarding excavations on the site of Jam during the month of A ugust 2003.

In 2002, U N ESC 0 and the Society for the Preservation of A fghanistan's Cultural Heritage (SPACH) jointly financed the tile-making workshop in $\mathrm{H}$ erat which they had revived in 1994. There are currently $60 \mathrm{~A}$ fghan trainees at the workshop, learning how to manufacture traditional tiles. In December 2003, the G erman authorities approved a U N ESC 0 Funds-in-Trust project for the retiling of the $G$ owhar Shad M ausoleum at the cost of U S\$120,000. The traditional tiles needed for this project are now being produced at the tilemaking workshop in Herat.

In February and M arch 2004, Professors A ndrea Bruno and Claudio $M$ argottini and a representative of U N ESC $O$ carried out a mission to Jam to advise the $A$ fghan $M$ inistry of Information and Culture on the construction of a road and bridge at the site. The mission resulted in the signature of a joint agreement by the local communities of Jam, the A fghan government and U N ESC $O$, allowing the organization to resume its operational activities to consolidate and restore the minaret and preserve the surrounding archaeological remains. The necessary geophysical surveys, followed by detailed technical subsoil investigations, will be executed as soon as possible to prepare for the minaret's long-term consolidation.

\section{Kabul Museum}

The Kabul M useum has suffered tremendously in the past 24 years of conflict in A fghanistan. During that period it was extensively looted and destroyed. Before the Taliban arrived in the capital in 1996, the museum was temporarily closed and its collections were deposited at various locations in Kabul. From 1991 to 1996, many of its most precious items disappeared, such as the Begram ivories, the entire numismatic collection, most Buddha statues, and fragments of wall paintings from the Bamiyan Valley. 
Immediately after the fall of the Taliban regime in December 2001, UNESCO sent a mission to identify and gather together the remains of various statues and objects in the Kabul M useum and to prepare a project for their restoration. In N ovember 2002, in view of the approach of winter, UNESCO took some emergency measures. N ew windows were installed in several rooms on the ground and first floor and a deep well with a pressure tank and plumbing was built to provide water for the conservation laboratory. In addition, a large el ectric generator was donated to supply electricity. In 2003, UNESCO, through SPACH, contributed US\$ 42,500 to the restoration of the museum, in particular for completion of the roof.

In January 2003, the Greek government started restoration of the Kabul M useum building as part of a commitment it had made during the Kabul Seminar held in M ay 2002, consisting of a donation of approximately U S\$ 750,000; UNESCO provided the G reek specialists with drawings and plans of the Kabul Museum produced by the organization's consultant, A ndrea Bruno. The US government also contributed U S\$100,000 to this project. The British International Security A ssistance Force (ISA F) has furthermore installed a new restoration laboratory composed of two rooms, one wet-room and one dry-room, both of which were funded by the British M useum. In addition, the French CEREDA F donated conservation equipment, while the newly created French DAFA, together with the Guimet $M$ useum in Paris, carried out training courses for the museum's curators that were begun by the Italian firm IsI A 0 in 2002.

In A pril/May 2003 and March 2004 a UNESCO expert, Bertille Lyonnet, undertook one-month missions to Kabul at the A fghan authorities' request in order to train staff from the $\mathrm{N}$ ational $\mathrm{M}$ useum in Kabul in the restoration of the ceramic collections.

\section{Summary of international cooperation and funding for rehabilitation of Afghanistan's cultural heritage}

Complementing its operational activities, U NESC 0 promotes existing normative instruments while developing new ones for the legal protection of tangible and intangible cultural heritage. $G$ iven that the prevention of illicit excavations and illicit trafficking is a major challenge in contemporary A fghanistan, U NESC 0 supports the efforts of the A fghan government to ban illicit excavations and control its borders to prevent smuggling of illicitly acquired movable cultural objects. 
In conclusion, it can be stated that to date, funding and other forms of assistance well exceeding the $\$ 7$ million pledged during the Kabul Seminar held in M ay 2002 have been given for cultural projects in A fghanistan. To summarize, the UNESCO Funds-in-Trust programme has been entrusted with the following amounts from donor countries: $\$ 1,815,967$ from the government of Japan for the conservation of Bamiyan; a further U $\$$ \$ 969,000 from the government of Italy for the monuments of Herat, Jam and the Kabul M useum; US\$705,000 from the Italian government for the G hazni museums, plus US\$67,460 for a Cultural Heritage Seminar to be held in Kabul in May 2004; US\$138,000 for Jam and US\$250,000 for Bamiyan from the Swiss government; and U $\$ \$ 850,000$ from the $G$ erman government in 2002, through ICOMOS Germany and the German A rchaeological Institute, for the restoration of the Babur $G$ ardens and to train A fghan archaeologists, as well as U S\$ 119,780 in 2003 for the retiling of the G owhar Shad M ausoleum.

Besides these Funds-in-Trust donations, bilateral contributions include U S\$ 5 million from the A ga Khan Trust for Culture for the restoration of the Babur $\mathrm{G}$ ardens and the Timur Shah M ausoleum in Kabul, and for the rehabilitation of traditional housing in Kabul, $\mathrm{H}$ erat and other cities. The $\mathrm{G}$ reek government has also earmarked $\$ 750,000$ for the restoration of the Kabul M useum building, and the U S government has contributed U S\$100,000 to this project. The French Délégation A rchéologique Française en A fghanistan has carried out preventive excavations. The French M usée G uimet and the Italian IsIA 0 team have conducted several training courses for the staff of the Kabul M useum, while the British M useum has restored three rooms at the Kabul M useum for the installation of a conservation laboratory. In addition, UNESCO has provided $\$ 400,000$ under its Regular Budget for the biennium 2002/03 for cultural activities in A fghanistan. In September 2002, U NESCO concluded a contract with the French NGO A gence d'A ide à la Coopération Technique et au Développement (A CTED) for the emergency repair of the protecting roof of the nine domes of the $\mathrm{H}$ adji Pyada mosque in Balkh - the oldest mosque in A fghanistan - in order to preserve it from the harsh winter weather.

A II U N ESC 0 activities are being implemented in accordance with the recommendations of the International Coordination Committee for the Safeguarding of A fghanistan's C ultural Heritage.

U N ESC 0 would like to take this opportunity to thank all of these generous donors for their invaluable contributions. It should al so be emphasized 
$\begin{array}{lllll}\text { RICE JOIN } & \text { IRRC JUNE } 2004 & \text { VoL. } 86 & \text { No } 854\end{array}$

411

that these cultural funds come from specific cultural budgets. As such, they have not been taken from humanitarian funds, but instead constitute a supplement to them. If activities such as those described above are to continue, further financial support will have to be found. 


\section{Résumé:}

\section{Le mandat de l'UNESCO et ses activités récentes pour la réhabilitation du patrimoine culturel de l'Afghanistan}

\section{Christian Manhart}

Le patrimoine culturel afghan a subi des pertes irréversibles au cours des deux dernières décennies de guerre. L'U N ESC 0 a contribué à la protection de ce patrimoine pendant de nombreuses années et continue à tout mettre en œuvre pour assurer sa sauvegarde. En janvier 2002, I'U N ESC 0 a été mandatée par le gouvernement intérimaire afghan pour assurer la coordination de l'ensemble des activités internationales en faveur de la sauvegarde de ce patrimoine, un rôle qu'elle assume par le biais du C omité international de coordination pour la sauvegarde du patrimoine culturel afghan. Ses activités concernent des secteurs clés tels que le développement d'une stratégie sur le long terme; le renforcement des capacités locales par la formation et l'équipement; l'application des conventions internationales; la documentation et la création d'inventaires nationaux; la reconstruction du musée national de Kaboul avec son laboratoire de conservation; la réhabilitation des musées de $\mathrm{G}$ hazni; la consolidation des fondations du minaret de $D$ jam; la conservation des quatrième et cinquième minarets et du mausolée de $\mathrm{G}$ awar Shad à H erat; la conservation des fragments des deux Bouddhas à Bamiyan ainsi que la consolidation des niches et falaises et la protection des peintures murales dans les grottes. 


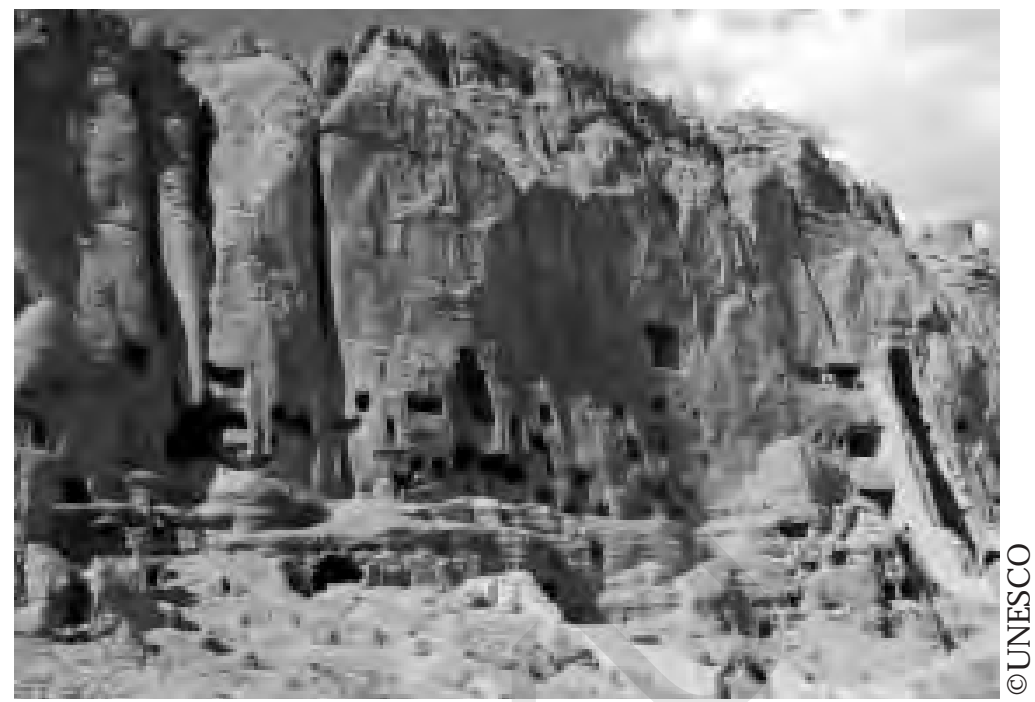

Buddhist caves in Bamiyan

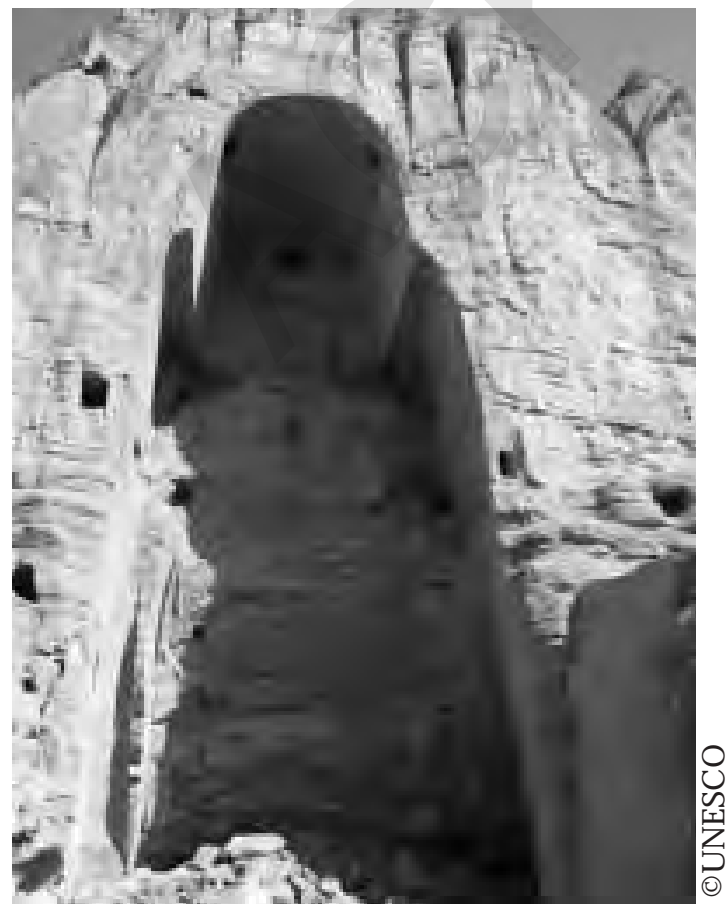

Bamiyan - N iche of Large Buddha 


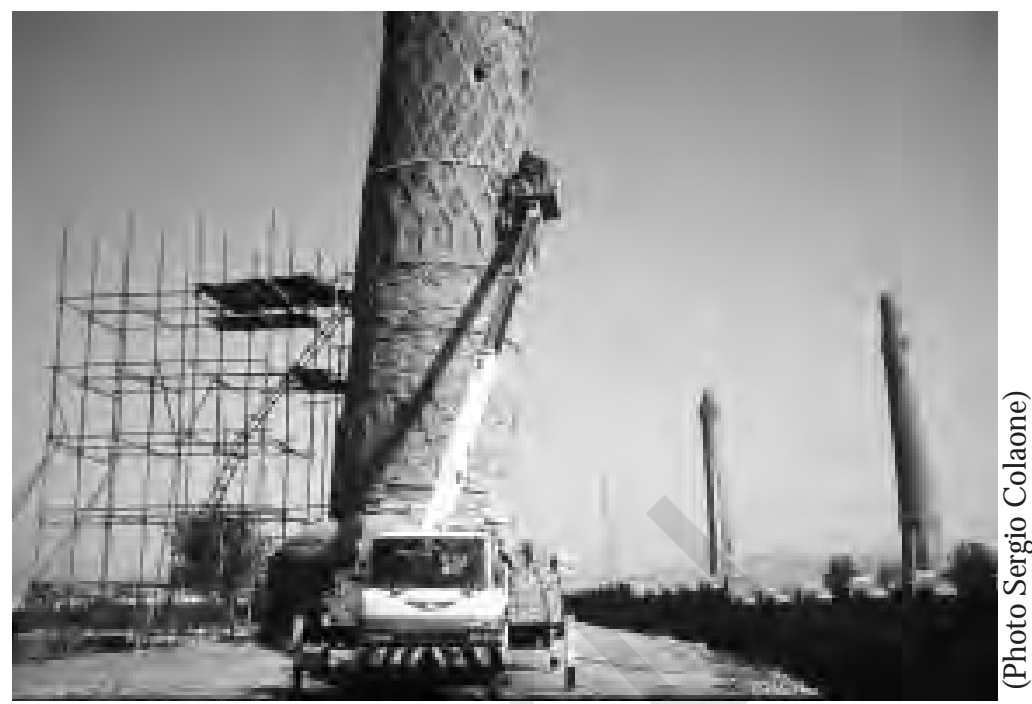

Emergency stabilisation works of the 5th minaret of Herat

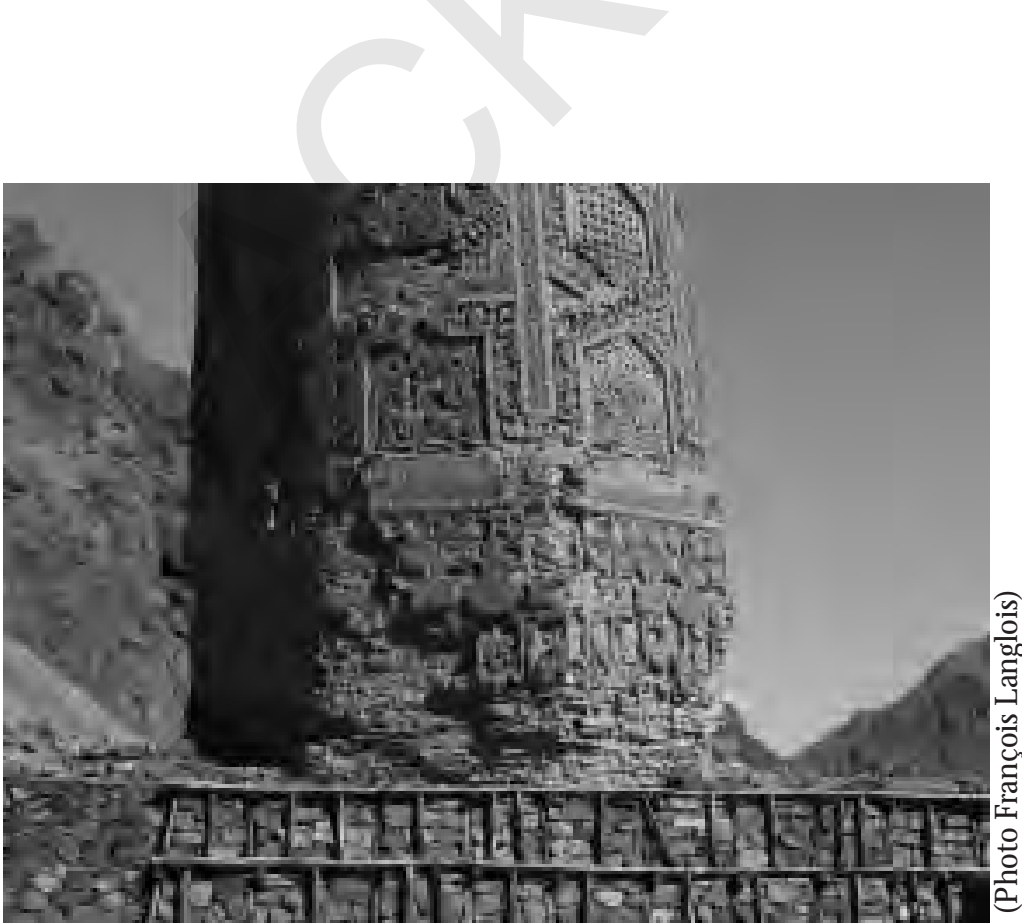

Jam - Gabion protection of the base of the minaret, carried out by U NESC 0 